\title{
МЕТАБОЛІЧНІ ЕФЕКТИ КОРВІТИНУ I ТІВОРТІНУ У ХВОРИХ НА ГІПЕРТОНІЧНУ ХВОРОБУ В ПОЄДНАННІ ЗІ СТАБІЛЬНОЮ ІШЕМІЧНОЮ ХВОРОБОЮ СЕРЦЯ ТА ЦУКРОВИМ ДІАБЕТОМ 2 ТИПУ
}

\author{
๑В. В. Бойко, С. В. Білецький, Т. В. Казанцева, О. А. Петринич \\ ВДНЗ України “Буковинський державний медичний університет», м. Чернівці
}

РЕзЮМЕ. При лікуванні гіпертонічної хвороби (ГХ), стабільної ішемічної хвороби серця (СІХС) та цукрового діабету 2 типу (ЦД 2) надзвичайно важливою $є$ корекція метаболічних факторів кардіоваскулярного ризику.

Метою роботи було дослідити ефективність лікування хворих на ГХ в поєднанні з СІХС та ЦД 2 шляхом впливу на інтенсивність пероксидного окиснення ліпідів (ПОЛ) і ендотеліальну дисфункцію інгібітором 5-ліпоксигенази Кверцетином (корвітином) і донатором NO - аргініну гідрохлоридом (тівортіном).

Матеріал і методи. У дослідження включено 65 хворих на ГX II стадії в поєднанні з СІХС та ЦД 2, які були рандомізовані в дві групи. У I групу входили 30 пацієнтів, яким проводили загальноприйняту базисну терапію. Пацієнтам II групи (35 осіб) перші 6 днів, крім базисної терапії, проводили інфузійну терапію корвітином (0,5 г), а в наступні 6 днів - тівортіном по 100 мл розчину внутрішньовенно з подальшим переходом на амбулаторний прийом пероральної форми тівортіну по 10 мл 2 рази на добу протягом двох тижнів.

Результати. Використання корвітину і тівортіну на тлі базисної терапії привело до достовірного зменшення концентрації глюкози плазми, імунореактивного інсуліну, індексу HOMA-IR, малонового альдегіду (MA) плазми та еритроцитів. 3 боку антиоксидантного захисту відмічено достовірне зростання вмісту глутатіону відновленого, підвищення активності глутатіонпероксидази, каталази. Виявлено достовірне зростання вмісту кінцевих метаболітів монооксиду нітрогену (NO) на 27,3 \%, ендотеліального судинного фактора росту VEGF-A - на 27 \%. У контрольній I групі хворих динаміка вивчених показників метаболізму в процесі лікування виявилася несуттєвою.

КЛючОВІ СлОВА: гіпертонічна хвороба; ішемічна хвороба серця; цукровий діабет; показники метаболізму; корвітин; тівортін.

Вступ. Останнім часом у терапії стали приділяти велику увагу проблемі ко- і поліморбідності. Загальновідомо, що артеріальна гіпертензія (АГ) найчастіше поєднується з IXC [1]. Особливо серйозною проблемою $є$ коморбідність АГ і ЦД 2, що пов'язано з більш раннім розвитком ураження органів-мішеней і наступними серцево-судинними катастрофами [2].

При діагностиці та лікуванні ГХ надзвичайно важливим $\epsilon$ вивчення впливу метаболічних факторів кардіоваскулярного ризику та їх медикаментозної корекції [3].

Мета дослідження - підвищити ефективність лікування Хворих на ГХ в поєднанні з СІХС та ЦД 2 шляхом впливу на інтенсивність ПОЛ і ендотеліальну дисфункцію (ЕД) інгібітором 5-ліпоксигенази кверцетином (корвітином) і донатором NO - аргініну гідрохлоридом (тівортіном).

Матеріал і методи дослідження. Обстежено 65 хворих на ГХ ІІ стадії (ст.) 1-3 ступенів в поєднанні з СІXC (стенокардія напруження I-II функціональних класів) та ЦД 2 (середнього ступеня тяжкості, субкомпенсованого). Вік хворих був від 36 до 72 років. Контрольну групу склали 26 практично здорових осіб, репрезентативних за віком і статтю.

Усі хворі були рандомізовані в дві групи. У I групу увійшли 30 пацієнтів, які отримували комплексну базисну терапію (БТ) (інгібітори ангіотензинперетворювального ферменту, антагоністи кальцію, нітрати, бета-адреноблокатори, статини, антиагреганти, цукрознижувальні препарати). Пацієнтам II групи (35 осіб) перші 6 днів на тлі БТ проводили інфузійну метаболічну терапію корвітином $(0,5$ г), а в наступні 6 днів - тівортіном по 100 мл розчину в/в з подальшим переходом на амбулаторний прийом пероральної форми тівортіну по 10 мл 2 рази на добу протягом двох тижнів.

Досліджували вміст глюкози у сироватці крові натще $з$ використанням набору тест-систем (BIO-LA-TEST, компанії Erba Lachema, Чехія) [4]. Piвень у крові інсуліну натще визначали з використанням стандартних наборів фірми Monobind inc. (США) методом імуноферментного аналізу. Нормальними величинами концентрації інсуліну натще вважали для чоловіків до 25 мкОд/мл, для жінок - до 23 мкОд/мл [5]. Для оцінки ступеня резистентності до інсуліну використовували малу модель гомеостазу (Homeostasis Model Assessment - HOMA) з визначенням показника НОМАIR, запропонованого D. Matthews і співавт., який обчислювали за формулою: інсулін крові натще (мкОд/мл) х глюкоза плазми крові натще (ммоль/л)/22,5.

Стан ліпідного обміну вивчали шляхом визначення загального холестеролу (ЗХС), холестеролу ліпопротеїнів високої щільності (ХС ЛПВЩ), триацилгліцеролів (ТГ) з використанням діагностичних стандартних наборів фірми ТОВ НВП «Філісіт-Діагностика». Рівень холестеролу ліпопротеїнів низької щільності (ХС ЛПНЩ) визначали за 
Огляди літератури, оригінальні дослідження, погляд на проблему формулою W. Friedewald: XС лПНЩ = 3ХC - XC лПВЩ - ТГ/2,2.

Про стан ПОЛ та антиоксидантного захисту (АОЗ) до та після лікування судили за рівнями МА у плазмі та еритроцитах, вмістом у плазмі глутатіону відновленого (ГВ), глутатіонпероксидази (ГП), каталази (КТ).

Стан ендотеліальної функції оцінювали шляхом визначення продукції NO в організмі за сумарним рівнем його кінцевих метаболітів (нітритів та нітратів) у плазмі крові [6].

Дослідження вмісту ендотеліального судинного фактора росту людини (VEGF-A) в сироватці крові проводили імуноферментним методом 3 використанням стандартного набору «Human VEGF-A ELISA» фірми RayBiotech, Inc. (США).

Статистичну обробку результатів дослідження проводили шляхом визначення середніх арифметичних величин (М) та стандартної похибки (m). Перевірку розподілу вибірок на нормальність здійснювали за критерієм Шапіро-Уілка. Вірогід- ність змін у разі нормального розподілу у вибірках визначали за критерієм Стьюдента, в інших випадках застосовували критерій Уілкоксона. Відмінність між вибірками вважали статистично вірогідною при р<0,05.

Результати й обговорення. Показники метаболізму у обстежених хворих представлені в таблиці 1. Як видно з даних, наведених у таблиці 1, в обох групах хворих вихідні показники (до лікування) вуглеводного, ліпідного обміну, ПОЛ, АОЗ, кінцеві метаболіти NO суттєво відрізнялися від таких у здорових ( $<<0,05)$. Зростання активності ГП, КТ у обстежуваних хворих, ймовірно, $є$ компенсаторним, що зумовлено більш інтенсивним використанням ГВ для знешкодження зростаючої кількості продуктів ПОЛ. Підвищення вмісту кінцевих метаболітів NO можна трактувати як відповідну реакцію організму на гіперпродукцію вазоконстрикторів в умовах оксидативного стресу за рахунок активації індуцибельної NO-синтетази, на що вказують й інші автори [7].

Таблиця 1. Метаболічні показники у хворих на ГX II ст. в поєднанні з IXС та ЦД 2 під впливом лікування корвітином і тівортіном впродовж 14 днів ( $\mathrm{M} \pm \mathrm{m})$

\begin{tabular}{|c|c|c|c|c|c|}
\hline \multirow[t]{2}{*}{ Показник } & \multirow{2}{*}{$\begin{array}{c}\text { Здорові, } \\
\text { n=26 }\end{array}$} & \multicolumn{2}{|c|}{$\begin{array}{c}\text { Контрольна група } \\
\text { (базисна терапія), } \\
\text { n=30 }\end{array}$} & \multicolumn{2}{|c|}{$\begin{array}{c}\text { Основна група } \\
\text { (базисна + метаболічна терапія), } \\
\text { n=35 }\end{array}$} \\
\hline & & до лікування & $\begin{array}{c}\text { після } \\
\text { лікування }\end{array}$ & до лікування & $\begin{array}{c}\text { після } \\
\text { лікування }\end{array}$ \\
\hline Глюкоза натще, ммоль/л & $4,56 \pm 0,07$ & $8,28 \pm 0,33^{*}$ & $7,91 \pm 0,23^{*}$ & $8,19 \pm 0,30 *$ & $7,60 \pm 0,21 * / * *$ \\
\hline IPI натще, мкОд/мл & $11,06 \pm 1,14$ & $29,86 \pm 1,96 *$ & $28,02 \pm 1,77 *$ & $29,25 \pm 2,04^{*}$ & $23,16 \pm 1,41 * / * *$ \\
\hline HOMA-IR & $2,37 \pm 0,23$ & $10,77 \pm 1,45^{*}$ & $9,68 \pm 1,37^{*}$ & $10,57 \pm 1,56^{*}$ & $7,75 \pm 1,28 * / * *$ \\
\hline ЗХС, ммоль/л & $4,09 \pm 0,23$ & $6,05 \pm 0,27^{*}$ & $5,75 \pm 0,44^{*}$ & $5,99 \pm 0,29 *$ & $5,52 \pm 0,26^{*}$ \\
\hline ТГ, ммоль/л & $1,14 \pm 0,07$ & $2,08 \pm 0,28^{*}$ & $1,84 \pm 0,24^{*}$ & $2,18 \pm 0,22^{*}$ & $1,79 \pm 0,22^{*}$ \\
\hline ХС ЛПВЩ, ммоль/л & $1,39 \pm 0,03$ & $0,83 \pm 0,04 *$ & $0,85 \pm 0,05^{*}$ & $0,80 \pm 0,05^{*}$ & $0,91 \pm 0,05^{*}$ \\
\hline ХС лПНЩ, ммоль/л & $2,48 \pm 0,08$ & $4,17 \pm 0,21^{*}$ & $3,91 \pm 0,24^{*}$ & $4,13 \pm 0,18^{*}$ & $3,87 \pm 0,20 *$ \\
\hline МА плазми, мкмоль/л & $2,49 \pm 0,26$ & $6,75 \pm 0,41^{*}$ & $6,31 \pm 0,39 *$ & $6,16 \pm 0,34^{*}$ & $5,41 \pm 0,26 * / * *$ \\
\hline МА еритроцитів, мкмоль/л & $6,69 \pm 0,37$ & $9,21 \pm 0,66^{*}$ & $8,84 \pm 0,59 *$ & $9,66 \pm 0,62^{*}$ & $8,96 \pm 0,50 * / * *$ \\
\hline ГВ, ммоль/л & $0,86 \pm 0,04$ & $0,55 \pm 0,03 *$ & $0,59 \pm 0,04^{*}$ & $0,57 \pm 0,02 *$ & $0,63 \pm 0,04 * / * *$ \\
\hline ГП, нмоль ГВ за 1 хв на 1 г Нв & $184,56 \pm 8,86$ & $211,23 \pm 7,97 *$ & $217,14 \pm 8,13^{*}$ & $207,78 \pm 5,82 *$ & $225,74 \pm 6,14 * / * *$ \\
\hline Каталаза, мкмоль за 1 хв на 1 г Нв & $16,84 \pm 0,76$ & $19,73 \pm 0,88^{*}$ & $20,14 \pm 1,22 *$ & $20,23 \pm 1,14^{*}$ & $24,96 \pm 1,08 * / * *$ \\
\hline Кінцеві метаболіти NO, мкмоль/л & $21,14 \pm 0,78$ & $27,12 \pm 1,93 *$ & $28,34 \pm 2,03 *$ & $26,59 \pm 1,84^{*}$ & $33,87 \pm 1,72 * / * *$ \\
\hline VEGF-A, пг/мЛ & & $95,15 \pm 12,44$ & $104,18 \pm 14,16$ & $105,64 \pm 13,23$ & $134,22 \pm 15,04 * \star$ \\
\hline
\end{tabular}

Примітки: 1. * - різниця вірогідна порівняно з показником у групі контролю (p<0,05);

2. ** - різниця вірогідна порівняно з показником до лікування $(p<0,05)$

Метаболічні показники у 65 хворих на ГХ II стадії в поєднанні з СІХC і ЦД 2 в процесі лікування наведені в таблиці 1. За результатами дослідження, використання корвітину і тівортіну на тлі БТ привело до достовірного зменшення концентрації глюкози плазми на $7,2 \%$, IPI - на 20,8 \%, індексу НОМАIR - на 26,7 \%, МА плазми - на $12,1 \%$, МА еритроцитів - на 7,2 \%. 3 боку АОЗ відмічено достовірне зростання вмісту ГВ на 10,5 \%, підвищення активності ГП на 8,6 \% і КТ - на 23,4 \%. Виявлено достовірне зростання вмісту кінцевих метаболітів NO на $27,3 \%$, ендотеліального судинного фактора росту VEGF-A - на $27 \%$.

У контрольній I групі хворих динаміка вивчених показників метаболізму в процесі лікування виявилася несуттєвою. 
Огляди літератури, оригінальні дослідження, погляд на проблему

Наступним етапом роботи була оцінка стійкості ефекту стаціонарного лікування після двотижневого амбулаторного прийому пероральної форми тівортіну. Отримані результати показали збереження досягнутої на стаціонарному етапі достовірної позитивної динаміки показників вуглеводного обміну з тенденцією до їх покращання. 3 боку ліпідного обміну встановлено достовірне поліпшення показників ЗХС, ТГ, ХС ЛПВЩ, ХС лПнЩ. Слід зазначити, що до кінця стаціонарного етапу лікування відзначена лише тенденція до зниження концентрації ЗХС, ТГ, ХС лПнЩ, підвищення вмісту ХС ЛПВЩ.

Отже, активація процесів ПОЛ та пригнічення АОЗ у хворих з ГХ, СІХС, ЦД, та з їх поєднаним перебігом обґрунтовує доцільність призначення антиоксидантів для профілактики і терапії. Загальновідома антиоксидантна активність біофлавоноїдів. Одним 3 найпотужніших антиоксидантів серед біофлавоноїдів $€$ кверцетин $[8,9]$.

До метаболітотропних кардіопротекторів можна віднести також L-аргінін - субстрат для синтезу NO. Згідно з дослідженнями, біохімічні зміни, що лежать в основі дефіциту NO і дисфункції ендотелію, можуть індукувати розвиток гіпертензії і атеросклерозу [10-12]. На сьогодні вважається, що основним механізмом антиатеросклеротичної дії кверцетину та його похідних $\epsilon$ інгібування окиснення ліпопротеїнів низької щільності в атеросклеротичних бляшках і вибіркове накопичення активних метаболітів кверцетину в пінистих клітинах [13].

За нашими даними, метаболітотропна терапія хворих на ГХ в поєднанні зі СІХС та ЦД 2 з використанням тівортіну привела до статистично достовірного збільшення вмісту ендотеліального судинного фактора росту VEGF-A. Доведено, що NO $\epsilon$ тригером зростання і диференціації клітин, що беруть участь в ангіогенезі, за допомогою активації конститутивної NO-синтетази, експресії фактора росту ендотелію судин. Показовим підтвердженням ролі NO в активації процесу ангіогенезу можна вважати дані експериментального дослідження, в якому було продемонстровано, що блокування синтезу NO ендотелієм знижує синтез VEGF-A на $40 \%$ [14].

Патогенетичне обгрунтування послідовного застосування корвітину і тівортіну для корекції метаболічних порушень випливає з ролі оксидантного стресу у виникненні ЕД, зниження утворення i біодоступності NO у хворих на ГХ, СІХС, ЦД.

Висновки. 1. Метаболітотропна терапія корвітином і тівортіном позитивно вплинула на показники вуглеводного і ліпідного обміну, поЛ та АОЗ крові у хворих на ГX ІІ Ст. в поєднанні з СІХС та ЦД 2. Встановлено достовірне зменшення концентрації глюкози плазми, IPI, індексу HOMA-IR, ЗХС, ХС ЛПНЩ, збільшення вмісту ХС ЛПВЩ, зменшення концентрації МА плазми та еритроцитів. Зниження інтенсивності процесів ПОЛ супроводжувалося активацією систем АОЗ: відзначено достовірне зростання вмісту ГВ, підвищення активності ГП і КТ. Виявлено достовірне зростання вмісту кінцевих метаболітів NO, концентрації ендотеліального судинного фактора росту людини VEGF-A. У контрольній групі пацієнтів динаміка зазначених показників на фоні тільки базисної терапії виявилася несуттєвою.

2. Корекція метаболічних порушень у хворих на ГХ з коморбідною СІХС та ЦД 2 може бути досягнута шляхом послідовного використання антиоксидантів (корвітину) та донаторів NO (тівортіну).

Перспективи подальших досліджень. Вивчення у хворих на ГХ в поєднанні зі СІХС та ЦД 2 типу ефективності метаболітотропної терапії в залежності від поліморфізму гена PPARү2.

\section{ЛІТЕРАТУРА}

1. Масляева Л. В. К проблеме сочетаний артериальной гипертензии с ишемической болезнью сердца и сердечной недостаточностью: все ли изучено? Часть I. Артериальная гипертензия и ишемическая болезнь сердца / Л. В. Масляева, С. Н. Коваль // Укр. терапевт. ж. - 2006. - № 3. - С. 76-83.

2. Біловол О. М. Коморбідність гіпертонічної хвороби та цукрового діабету 2 типу - актуальна проблема сучасної медицини / О. М. Біловол, А. С. Шалімова, М. М. Кочуева //Укр. терапевт. ж. -2014. - № 1. - С. 11-17.

3. Метаболічний синдром у пацієнтів з артеріальною гіпертензією та метаболічні ефекти різних антигіпертензивних препаратів / Ю. М. Сіренко, О. Л. Рековець, С. Ю. Савицький [та ін.] // Артериал. гипертензия. - 2010. - № 4 (12). [Електронний ресурс]. - Режим

доступу: http:// www.mif-ua.com/archive/article/13618 (24.01.2013)

4. Методи клінічних та експериментальних досліджень в медицині / Л. В. Беркало, О. В. Бобович, Н. О. Боброва [та ін.]; під ред. І. П. Кайдашева. - Полтава : Полімет, 2003. - 320 c.

5. Associations of insulin levels with left ventricular structure and function in American Indians / A. Ilercil, R. B. Devereux, M. R. Roman [et al.] // Diabetes. - 2002. Vol. 51, No. 5. - P. 1543-1547.

6. Nitrite and nitrate determination in plasma: a critical evaluation / H. Moshage, B. Kok, R. Huzenga [et al.] // Clin. Chem. - 1995. - Vol. 41. - P. 892-896.

7. Бобров В. А. Метаболизм оксида азота и эндотелиальная дисфункция у больных с эссенциальной ги- 
Огляди літератури, оригінальні дослідження, погляд на проблему

пертензией с признаками ремоделирования левого желудочка / В. А. Бобров, И. Г. Фирсова // Укр. кардіол. ж. $-2010 .-$ № 3. - С. 58-63.

8. Про- та антиоксидантна системи і патологічні процеси в організмі людини / О. Г. Резніков, О. М. Полумбрик, Я. Г. Бальон [та ін.] // Вісн. НАН України. - 2014. № 10. - С. 17-29.

9. Киричек Л. Т. Метаболитные и метаболитотропные препараты в системе стресспротекции / Л. Т. Киричек, Н. Г. Щербань // Международ. мед. журн. - 2012. № 2. - С. 103-108.

10. Небиеридзе Д. В. Дисфункции эндотелия и ее коррекции при артериальной гипертонии / Д. В. Небиеридзе // Рус. мед. ж. - 2006. - № 2. - С. 127-131.

\section{REFERENCES}

1. Maslyayeva, L.V., \& Koval, S.N. (2006). K probleme sochetaniy arterialnoy gipertenzii s ishemicheskoy boleznyu serdtsa i serdechnoy nedostatochnostyu: vse li izucheno? Chast I. Arterialnaya gipertenziya i ishemicheskaya bolezn serdtsa [On the issue of association of arterial hypertension with ischemic heart disease and heart failure: is everything investigated? Part I. Arterial hypertension and ischemic heart disease]. Ukr. terapevt. zh. - Ukrainian Therapeutic Journal, 3, 76-83 [in Russian].

2. Bilovol, O.M., Shalimova, A.S., Kochueva, M.M. (2014). Komorbidnist hipertonichnoi khvoroby ta tsukrovoho diabetu 2 typu - aktualna problema suchasnoi medytsyny [Comorbidity of essential hypertension and type 2 diabetes mellitus - a topical issue of modern medicine]. Ukr. terapevt. zh. - Ukrainian Therapeutic Journal, 1, 11-17 [in Ukrainian].

3. Sirenko, Yu.M., Rekovets, O.L., \& Savytskyi, S.Yu. (2010). Metabolichnyi syndrom u patsiientiv z arterialnoiu hipertenziieiu ta metabolichni efekty riznykh antyhipertenzyvnykh preparativ [Metabolic syndrome in patients with arterial hypertension and metabolic effects of different antihypertensive drugs]. Arterial. hipertenziia - Arterial Hypertension, 4 (12). - Retrieved from: http:// www.mif-ua. com/archive/article/13618 (24.01.2013) [in Ukrainian].

4. Berkalo, L.V., Bobovych, O.V., \& Bobrova, N.O. (2003). Metody klinichnykh ta eksperymentalnykh doslidzhen $v$ medytsyni [Methods of clinical and experimental studies in medicine]. Kaidasheva, I.P. (Ed.), Poltava: Polimet [in Ukrainian].

5. Ilercil, A., Devereux, R.B., \& Roman, M.R. (2002). Associations of insulin levels with left ventricular structure and function in American Indians. Diabetes., 51 (5), 1543-1547.

6. Moshage, H., Kok, B., \& Huzenga, R. (1995). Nitrite and nitrate determination in plasma: a critical evaluation. Clin. Chem., 41, 892-896.

7. Bobrov, V.A., \& Firsova, I.G. (2010). Metabolizm oksida azota i endotelialnaya disfunktsiya u bolnykh s essen-
11. Tiritilli A. Nitric oxide (NO), vascular protection factor. Biology, physiological role and biochemistry of NO / A. Tiritilli //Presse Med.-1998.-Vol. 27 (21).-P. 1061-1064.

12. Малая Л. Т. Эндотелиальная дисфункция при патологии сердечно-сосудистой системы / Л. Т. Малая, А. Н. Корж, Л. Б. Балковая. - Харьков : Форсинг, 2000. $432 \mathrm{c}$.

13. Macrophage as a target of quercetin glucuronides in human atherosclerotic arteries /Y. Kawai, T. Nishikawa, T. Shiba [et al.] // J. Biol. Chem. - 2008. - Vol. 283. - P. 9424-9434.

14. Возможности повышения эффективности антигипертензивной терапии: роль донаторов оксида азота / В. Ю. Жаринова, Е. И. Парасюк, И. А. Самоць [и др.] // Здоров'я України. - 2016. - №1 (44). - С. 45-46.

tsialnoy gipertenziyey c priznakami remodelirovaniya levogo zheludochka [Nitrogen oxide metabolism and endothelial dysfunction in patients with essential hypertension with the signs of left ventricle remodeling]. Ukr. kardiol. zh. - Ukrainian Cardiology Journal, 3, 58-63 [in Russian].

8. Reznikov, O.H., Polumbryk, O.M., \& Balon, Ya.H. (2014). Pro- ta antyoksydantna systemy i patolohichni protsesy v orhanizmi liudyny [Pro- and antioxidant systems and pathological processes in the human organisms]. Visn. NAN Ukrainy - Herald of National Academy of Sciences of Ukraine, 10, 17-29 [in Ukrainian].

9. Kirichek, L.T., \& Shcherban, N.G. (2012). Metabolitnyye i metabolitotropnyye preparaty $v$ sisteme stressprotektsii [Metabolic and metabolitotropic drugs in stressprotection system]. Mezhdunarod. med. zhurn. - International Medical Journal, 2, 103-108 [in Russian].

10. Nebiyeridze, D.V. (2006). Disfunktsii endoteliya i yeyo korrektsii pri arterialnoy gipertonii [Endothelial dysfunction and its correction in case of arterial hypertension]. Rus. med. zh. - Russian Medical Journal, 2, 127-131 [in Russian].

11. Tiritilli, A. (1998). Nitric oxide (NO), vascular protection factor. Biology, physiological role and biochemistry of NO. Presse Med., 27 (21), 1061-1064.

12. Malaya, L.T., Korzh, A.N., \& Balkovaya, L.B. (2000). Endotelialnaya disfunktsiya pri patologii serdechno-sosudistoy sistemy [Endothelial dysfunction with pathology of the cardio-vascular system]. Kharkiv: Forsing [in Russian].

13. Kawai, Y., Nishikawa, T., \& Shiba, T. (2008). Macrophage as a target of quercetin glucuronides in human atherosclerotic arteries. J. Biol. Chem., 283, 9424-9434.

14. Zharinova, V.Yu., Parasyuk, Ye.I., \& Samots, I.A. (2016). Vozmozhnosti povysheniya effektivnosti antigipertenzivnoy terapii: rol donatorov oksida azota [Possibilities to increase efficacy of anti-hypertensive therapy: the role of nitrogen oxide donators]. Zdorovia Ukrainy - Health of Ukraine, 1 (44), 45-46 [in Russian]. 
Огляди літератури, оригінальні дослідження, погляд на проблему

\title{
МЕТАБОЛИЧЕСКИЕ ЭФФЕКТЫ КОРВИТИНА И ТИВОРТИНА У БОЛЬНЫХ ГИПЕРТОНИЧЕСКОЙ БОЛЕЗНЬЮ В СОЧЕТАНИИ СО СТАБИЛЬНОЙ ИШЕМИЧЕСКОЙ БОЛЕЗНЬЮ СЕРДЦА И САХАРНЫМ ДИАБЕТОМ 2 ТИПА
}

\author{
ОВ. В. Бойко, С. В. Билецкий, Т. В. Казанцева, О. А. Петринич
}

ВГУз Украины «Буковинский государственный медицинский университет», г. Черновцы

PЕЗЮМЕ. При лечении гипертонической болезни (ГБ), стабильной ишемической болезни сердца (СИБС) и сахарного диабета 2 типа (СД 2) чрезвычайно важной является коррекция метаболических факторов кардиоваскулярного риска.

Цель работы - исследовать эффективность лечения больных ГБ в сочетании со СИБС и СД 2 путем воздействия на интенсивность перекисного окисления липидов (ПОЛ) и эндотелиальной дисфункции ингибитором 5-липоксигеназы кверцетином (корвитином) и донатором NO - аргинина гидрохлоридом (тивортином).

Материал и методы. В исследование включено 65 больных ГБ ІІ стадии в сочетании со СИБС и СД 2, которые были рандомизированы в две группы. В I группу входили 30 пациентов, которым проводилась общепринятая базисная терапия. Пациентам II группы (35 человек) первые 6 дней, кроме базисной терапии, проводилась инфузионная терапия корвитином (0,5 г), а в последующие 6 дней - тивортином по 100 мл внутривенно с последующим переходом на амбулаторный прием пероральной формы тивортина по 10 мл (2 мерные ложки) 2 рази в сутки на протяжении двух недель.

Результаты. Использование корвитина и тивортина на фоне базисной терапии привело к достоверному снижению концентрации глюкозы плазмы, иммунореактивного инсулина, индекса HOMA-ИR, малонового альдегида (MA) плазмы и эритроцитов. Со стороны антиоксидантной защиты отмечено достоверное повышение содержания глутатиона восстановленного, повышение активности глутатионпероксидазы, каталазы. Выявлено достоверное повышение содержания конечных метаболитов монооксида азота (NO) на 27,3 \%, эндотелиального сосудистого фактора роста VEGF-A - на 27 \%. В контрольной I группе больных динамика изученных показателей метаболизма в процессе лечения оказалась несущественной.

КЛЮчЕВЫЕ СЛОВА: гипертоническая болезнь; ишемическая болезнь сердца; сахарный диабет; показатели метаболизма; корвитин, тивортин.

\section{METABOLIC EFFECTS OF CORVITIN AND TIVORTIN IN PATIENTS WITH ESSENTIAL HYPERTENSION ASSOCIATED WITH STABLE ISCHEMIC HEART DISEASE AND TYPE 2 DIABETES MELLITUS}

\author{
@V. V. Boyko, S. V. Biletskyi, T. V. Kazantseva, O. A. Petrynych \\ Bukovinian State Medical University, Chernivtsi
}

SUMMARY. Correction of metabolic factors of cardiovascular risk is especially important in the treatment of essential hypertension (EH), stable ischemic heart disease (SIHD) and type 2 diabetes mellitus (DM).

The aim of the study - to investigate the efficacy of treatment of patients suffering from EH associated with SIHD and type 2 DM by means of the action of Quercetin (Corvitin), 5-lipoxygenase inhibitor, and arginine hydrochloride (Tivortin), NO donator, on the intensity of lipid peroxide oxidation (LPO) and endothelial dysfunction.

Material and Methods. The study involved 65 patients suffering from EH II stage associated with SIHD and type 2 diabetes mellitus. They were randomized into two groups. Group I included 30 patients administered to common basic therapy. In addition to basic therapy the patients of group II (35 individuals) during the first six days were given infusions with Corvitin $(0,5 \mathrm{~g})$, followed by another six days - with Tivortin per $100 \mathrm{ml}$ i/v with further changing to out-patient Tivortin intake orally in the dose of $10 \mathrm{ml}$ (2 measuring spoons) twice a day during two weeks.

Results. Administration of Corvitin and Tivortin against the ground of basic therapy resulted in reliable decrease of plasma glucose concentration, immunoreactive insulin, HOMA-ИR index, malonic aldehyde (MA) of plasma and erythrocytes. From the side of antioxidant protection a reliable increase of reduced glutathione content, increased activity of glutathione peroxidase, and catalase were found. A reliable $27.3 \%$ increase of the content of final nitrogen monoxide metabolites, $27 \%$ increase of vascular endothelial growth factor - A (VEGF-A) were determined. In the control group I the dynamics of the examined metabolic indices in the process of treatment appeared to be inconsiderable.

KEY WORDS: essential hypertension; ischemic heart disease; diabetes mellitus; metabolic indices; corvitin; tivortin. 